\title{
THE INFLUENCE OF HEADMASTER LEADERSHIP AND ENVIRONMENT TOWARD COMPETENCY OF TEACHERS IN MUHAMMADIYAH PRIMARY SCHOOL IN BONTONOMPO, GOWA
}

\author{
Juhamri \\ Pascasarjana Universitas Islam Negeri Alauddin Makassar \\ Jln. H.M. Yasin Limpo, No. 36 Samata Gowa \\ Email: juhamri@gmail.com
}

\begin{abstract}
This research examines the influence of headmaster leadership as well its circumstances toward the competence of teachers in Muhammadiyah Primary school. It employs a quantitative research methodology. The results of the questionnaire processed show that the influence of the leadership of the head of the madrasah and the madrasah environment together on the professional competence of Madrasah Ibtidaiyah Muhammadiyah teachers in Bontonompo and South Bontonompo Districts, Gowa Regency is not positive. However, the researchers suggest that the influence of the Leadership of Madrasah Principals on Professional Competence is positive. The results of this study are related to Muhammad Surya's theory which states that the school environment includes living objects in the form of the closest human being in the form of the closest human that surrounds him, namely the family. Family is the main and first educational environment because humans get education for the first time from the family environment before knowing other environments.
\end{abstract}

Keywords: Competence, Environment, Leadership, Influence 


\section{Introduction}

Education is an investment in human resource development and is seen as a basic need for people who want to advance. The components of the education system that include human resources can be classified into two, namely: teacher and non-teacher education personnel. Regardless of the differences in these groups, both in terms of application, institutional structure, educational staff who are organized based on levels still have the same thing, namely aiming to educate the nation's life, explore and develop the potential of students to become human beings who believe and fear God Almighty, have noble character ${ }^{1}$, healthy, knowledgeable, capable, creative, independent, and become democratic and responsible citizens. To achieve this predicate requires guidance and guidance so that humans get the title "surrendered servant" as the ultimate goal of education ${ }^{2}$.

According to Syamsul Bachri Thalib, the national education standard contains a framework on what students should know, do, master and do at every level. This framework is presented in the form of developing basic sciences with scientific systematics that can be accounted for academically. This standard is also accompanied by a standard

${ }^{1}$ Muhamad Idris, Tips to Become a Professional Teacher (Cet. I; Yogyakarta: Ar-Ruzz Media, 2008), p. 20

${ }^{2}$ Hamzah B Uno, Educational Profession, Problems, Solutions, and Educational Reform in Indonesia (Cet. IV; Jakarta: Bumi Aksara, 2009), p. 27-28. 
for the formation of noble morals that prioritizes the formation of a value system to create Indonesian people with personalities and work ethics. ${ }^{3}$

Islam has further provided examples and images of a good education. The education in question is moral. Allah says in QS Luqman / 31: 17-18, which reads;

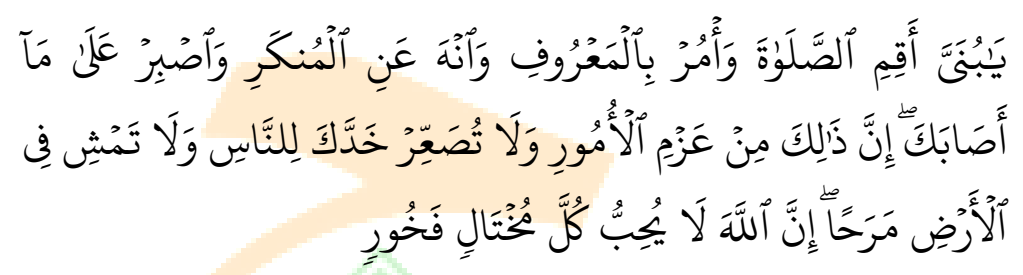

Translation;

O my child, establish prayers and tell (humans) to do good and prevent (them) from wrong actions and be patient with what happens to you. Indeed, this includes things that are required (by Allah). and do not turn away from men (because of pride), and do not walk the earth with pride. Indeed, Allah does not like those who are proud anymore. ${ }^{4}$

The verse is very clear that God gives the mandate to humans to remind each other or to do good behavior and of

${ }^{3}$ Syamsul Bachri Thalib, Educational Psychology Based on Applicative Empirical Analysis (Cet. II; Jakarta: Kencana Prenamedia Group, 2013), p. 11.

${ }^{4}$ Ministry of Religion of the Republic of Indonesia, Al-Qur'an and its Translation (Jakarta: Kencana, 2013), p. 396. 
course avoid themselves from despicable acts. The main foundation of the verse as previously described is that these efforts can be carried out by two groups, namely teacher and non-teacher teaching staff. Therefore, the authors conclude that the most suitable level according to the principle of reminding and encouraging each other in kindness is teacher education through formal institutions, namely madrasas. Madrasah is a form of educational institution that is complex and unique. It is complex because madrasas are organizations in which various dimensions are interrelated and mutually determine each other. While it is unique, it shows that madrasas as organizations have certain characteristics that are not shared by other organizations, namely characteristics that place madrasas in their character, where the teaching and learning process occurs where the culture of human life is carried out. Following the characteristics of madrasas as complex and unique organizations. A madrasah has the name of a madrasah principal, who is school personnel who are responsible for all school activities ${ }^{5}$

The head of the madrasah can be seen as a formal official, while from the other side the head of the madrasah can act as a manager, as a leader, as an educator, and the role of the head of the madrasah as staff. The success in implementing educational activities is determined by the head of the madrasah as the leader and also the teacher, in this case,

${ }^{5}$ Muhamad Saroni, Madrasah Management (Cet. II; Yogyakarta: Ar Russ, 2006), p. 7. 
the teaching staff and their staff. All components and supporting elements must be fulfilled. Not only determined by the input factor (input) in this case are prospective students, but the implementation of education involves a series of inputs, processes, outputs to outcomes. Principal leadership factors, madrasah environmental factors can also influence. The school environment is one of the external factors that affect teacher professional competence. The school environment is a condition that exists informal educational institutions that systematically carry out guidance, teaching, and training programs to help students develop their potential. $^{6}$

The existence of effective (successful) leadership is the key to organizational success in achieving its goals. Educators, in this case, a teacher, must have competencies that are required for professional educators as an indicator of their performance. As a teacher, he has at least four competencies, namely; academic competence, personality competence, social competence, and professional competence. The abilities and competencies of a teacher are also inseparable from the leadership model/style of a leader ${ }^{7}$. Profession refers to a job or position that demands expertise, responsibility, and loyalty to the profession.

${ }^{6}$ Imam Supardi, Environment, and Sustainability (Cet. II;

Bandung: PT Alumni, 2003), p. 28.

${ }^{7}$ Oemar Hamalik, Teacher Education Based on a Competency Approach, h. 30 . 
Professionalization refers to the process of making someone a professional through pre-service education. Professional also refers to the degree of a person's appearance as a professional or the appearance of a job as a profession. ${ }^{8}$

Some of the factors that affect teacher professionalism and performance include; teacher welfare, democratic leadership of school principals, a conducive working climate in schools, support from teacher families for their profession, moral support from school boards, school committees, students, and the community. Meanwhile, the criteria for successful school principals have several criteria, namely: trusting teaching staff, delegating duties and authority, adiraga, sharing and utilizing time, without tolerance for disability, caring for teaching staff, building a vision, developing institutional goals, being agile and assertive, at the same time. patient, daring to introspect, having consistency, being open, and having a high self-identity. ${ }^{9}$

\section{Methodology}

This type of research used in this research is descriptive quantitative research. Quantitative descriptive research is research that is used to compare two or more groups. In this study, researchers identified and described a

${ }^{8}$ E. Mulyasa, Becoming a Professional Teacher, Creating Creative and Fun Learning (Cet. VII; Bandung: Youth Rosda Karya, 2008), p. 11

${ }^{9}$ E. Mulyasa, Becoming a Professional Teacher, Creating Creative and Fun Learning, p. 51 
phenomenon without trying to describe a causal relationship ${ }^{10}$ The research location is Madrasah Ibtidaiyah Muhammadiyah in Bontonompo and South Bontonompo Districts, Gowa Regency. Madrasah Ibtidaiyah in question are MI Muhammadiyah Kacci-Kacci, MI Muhammadiyah Anasappu, MI Muhammadiyah Kampung Parang, MI Muhammadiyah Bontolangkasa, MI Muhammadiyah Katinting, MI Muhammadiyah Allu, MI Muhammadiyah Campagayya, MI Muhammadiyah Bontomakkiyo, MI Muhammadiyah Likuboddong, MI Muhammadiyah Mandengeng, MI Muhammadiyah Kampung Daeng, as well as MI Muhammadiyah Gallang. The location was based on the researcher's experience and ability to understand the condition of the madrasah.

The approach in this research is multidisciplinary because researchers divide it into various disciplines, namely:

1. Normative Theological Approach, in which the research discusses the relation to Islamic teachings which are sourced from religious texts, namely the alQur'an and al-Hadith to assess the merits of an act.

2. Educational Approach, which sees humans as divine beings who are in the process of development in physical and spiritual growth that require guidance to have physical and mental well-being.

10 Julia Brannen, Combining Qualitative and Quantitative Research Methods (Cet. III; Yogyakara: PustakaPelajar, Fourth Prints, 2002), h. 89. 
The population in this study were principals and teachers of Madrasah Ibtidaiyah Muhammadiyah in Bontonompo and Bontonompo Selatan Districts, Gowa Regency. The total population to be studied is 123 respondents in 12 madrasas. This population is the whole object that will be examined by researchers later in understanding the influence of Madrasah Principal Leadership and Madrasah Environment on the Professional Competence of Madrasah Ibtidaiyah Muhammadiyah Teachers in Bontonompo and South Bontonompo Districts, Gowa Regency. Also, in this study population, it will make it easier for us to understand things that are an important part of this research. The population composition is as follows:

\begin{tabular}{|c|l|c|c|}
\hline \multirow{2}{*}{ No } & \multicolumn{2}{|c|}{ Madrasah Name } & \multicolumn{2}{|c|}{ Total } \\
\cline { 3 - 4 } & & Women & Male \\
\hline 1 & MI Muhammadiyah Kacci-Kacci & 3 & 10 \\
\hline 2 & MI Muhammadiyah Anasappu & 2 & 7 \\
\hline 3 & MI Muhammadiyah Kampung Parang & 2 & 9 \\
\hline 4 & MI Muhmmadiyah Bontolangkasa & 2 & 7 \\
\hline 5 & MI Muhammadiyah Katinting & 1 & 10 \\
\hline 6 & MI Muhammadiyah Allu & 3 & 9 \\
\hline 7 & MI Muhammadiyah Campagayya & 2 & 6 \\
\hline 8 & MI Muhammadiyah Bontomakkiyo & 3 & 7 \\
\hline 9 & MI Muhammadiyah Likuboddong & 2 & 9 \\
\hline 10 & MI Muhammadiyah Mandengeng & 2 & 7 \\
\hline 11 & MI Muhammadiyah Kampung Daeng & 1 & 8 \\
\hline 12 & MI Muhammadiyah Gallang & 2 & 9 \\
\hline \multicolumn{2}{|c|}{ Total } & $\mathbf{1 2 3}$ \\
\hline
\end{tabular}

Data source: Emis Madrasah Ibtidaiyah Muhammadiyah, Bontonompo and District Districts South Bontonompo, Gowa Regency. 
The sampling method used is the Random Sampling method, while the random sample is referred to as a simple method (Simple Random Sampling). Simple random sampling (Simple Random Sampling) is a sample taken in such a way that each research unit from a population has an equal chance of being selected as a sample. This study, researchers took a simple random sample (Simple Random Sampling) by way of a lottery. The number of simple random samples (Simple Random Sampling) to be taken in this study were 70 respondents from 123 populations in 12 Madrasah Ibtidaiyah Muhammadiyah in Bontonompo and Bontonompo Selatan Districts, Gowa Regency.

\section{Discussion}

1. Leadership of the Head of Madrasah Ibtidaiyah Muhammadiyah, Bontonompo, and South Bontonompo Districts, Gowa Regency

The head of the madrasah has a high responsibility in the development and implementation of existing activities in a madrasah, they are the people who are appointed in leadership and in making decisions that are considered important for the development of the madrasah. Regarding the condition of the head of madrasah in Madrasah Ibtidaiyah Muhammadiyah, Bontonompo and South Bontonompo Districts, Gowa Regency, the researcher found that there were 12 madrasah principals in each madrasah in Bontonompo and Bontonompo Selatan Districts, Gowa Regency. The principal or principal is the person who 
determines the focus and atmosphere of the school. Therefore, it is also said that successful schools are schools that have successful leaders. School leaders are those who are described as having high hopes for teachers and students. School leaders are those who know a lot about their assignments and determine the atmosphere of the school.

The following are the names of madrasas and the number of madrasah principals in Bontonompo and South Bontonompo Districts, Gowa Regency:

\begin{tabular}{|l|l|l|l|}
\hline No & \multicolumn{1}{|c|}{ Madrasah Name } & \multicolumn{1}{|c|}{ Name } & \multicolumn{1}{|c|}{ Status } \\
\hline 1 & $\begin{array}{l}\text { MI Muhammadiyah } \\
\text { Kacci-Kacci }\end{array}$ & Nur Mu'min, S.Ag & Non PNS \\
\hline 2 & $\begin{array}{l}\text { MI Muhammadiyah } \\
\text { Anasappu }\end{array}$ & Juliati, S.Pd.I & PNS \\
\hline 3 & $\begin{array}{l}\text { MI Muhammadiyah } \\
\text { Kampung Parang }\end{array}$ & Bahria, S.Pd & PNS \\
\hline 4 & $\begin{array}{l}\text { MI Muhammadiyah } \\
\text { Bontolangkasa }\end{array}$ & Faisal, S.Pd., M.Pd.I & Non PNS \\
\hline 5 & $\begin{array}{l}\text { MI Muhammadiyah } \\
\text { Katinting }\end{array}$ & Kasipah, S.Pd.I & PNS \\
\hline 6 & $\begin{array}{l}\text { MI Muhammadiyah } \\
\text { Allu }\end{array}$ & Muh. Arif, S.Pd.I & PNS \\
\hline 7 & $\begin{array}{l}\text { MI Muhammadiyah } \\
\text { Campagayya }\end{array}$ & Nurfitriani, S.Pd.I & Non PNS \\
\hline 8 & $\begin{array}{l}\text { MI Muhammadiyah } \\
\text { Bontomakkiyo }\end{array}$ & Syukri Gazali, S.Pd.I & PNS \\
\hline 9 & $\begin{array}{l}\text { MI Muhammadiyah } \\
\text { Likuboddong }\end{array}$ & Syamsuddin, S.Ag.,M.Pd.I & PNS \\
\hline 10 & $\begin{array}{l}\text { MI Muhammadiyah } \\
\text { Mandengeng }\end{array}$ & Supiati, S.Pd I & Non PNS \\
\hline 11 & $\begin{array}{l}\text { MI Muhammadiyah } \\
\text { Kampung Daeng }\end{array}$ & Sohra, S.Pd.I & Non PNS \\
\hline 12 & $\begin{array}{l}\text { MI Muhammadiyah } \\
\text { Gallang }\end{array}$ & Drs. Jalanti & Non PNS \\
\hline Total & $\mathbf{1 2}$ & \\
\hline
\end{tabular}


Data source: Emis Madrasah Ibtidaiyah Muhammadiyah, Bontonompo District and South Bontonompo, Gowa Regency.

The results of data processing in the form of a questionnaire using the SPSS program were taken from a questionnaire related to the leadership problems of madrasah principals in Madrasah Ibtidaiyah Muhammadiyah, Bontonompo and Bontonompo Selatan Districts, Gowa Regency, which consisted of process indicators of influencing subordinates from number 1 to 5 , then the art of influencing subordinates from numbers 6 to 10 and the ability to influence subordinates from numbers 11 to 15 The data collection in question aims to provide answers to the questions in the research objective, namely to describe the leadership of the madrasah principals in Madrasah Ibtidaiyah Muhammadiyah, Bontonompo, and Bontonompo Selatan Districts, Gowa Regency data statistics as follows:

\begin{tabular}{|l|l|}
\hline N Valid & 70 \\
Missing & 0 \\
Mean & 56.70 \\
Std Error of Mean & 0.35 \\
Median & 56.00 \\
Mode & 54.00 \\
Minimu & 32.00 \\
m & 70.00 \\
Maximum & 2920.00 \\
\hline
\end{tabular}


The Influence Of Headmaster Leadership And Environment Toward Competency....

\section{Sum}

The table above shows the answers of 70 respondents regarding the statistical data on the leadership variable of the head of Madrasah Ibtidaiyah Muhammadiyah in Bontonompo and South Bontonompo Districts, Gowa Regency with an average level of respondent answers of 56.70 . While the total number of answers was 2920.00. Regarding the category average value of the variable $\mathrm{X} 1$ consists of 5 levels taken from the lowest mean value (Std Error of Mean) of 0.35 and the highest is 75.00 . The average data category for the $\mathrm{X} 1$ variable can be seen in the following table:

\begin{tabular}{|l|l|l|}
\hline No & Average value & Category \\
\hline 1 & $0,35-15,00$ & Very low \\
\hline 2 & $15,01-29,66$ & Low \\
\hline 3 & $29,67-44,32$ & Moderate \\
\hline 4 & $44,33-58,98$ & High \\
\hline 5 & $58,99-75,00$ & Very high \\
\hline
\end{tabular}

The average respondent's answer to the $\mathrm{X} 1$ variable was 56.70. These results are categorized as high, namely at the level of 44.33 - 58.98. So it can be concluded that the leadership of the head of Madrasah Ibtidaiyah Muhammadiyah in Bontonompo and South Bontonompo Districts, Gowa Regency is in the high category. 


\section{The Influence of the Principal Leadership}

The results of the correlation test using the SPSS program were taken from a questionnaire related to the problem of the relationship between the head of madrasah and the professional competence of teachers in Madrasah Ibtidaiyah Muhammadiyah, Bontonompo and Bontonompo Selatan Districts, Gowa Regency, which consisted of 15 question items each. The data collection in question aims to describe the influence of the headmaster's leadership on the professional competence of teachers in Madrasah Ibtidaiyah Muhammadiyah, Bontonompo and South Bontonompo Districts, Gowa Regency, the following statistical data are obtained:

\begin{tabular}{|rr|l|l|l|l|l|}
\hline \multirow{2}{*}{ Model } & \multicolumn{3}{|l|}{ Correlations } & \multicolumn{2}{l|}{$\begin{array}{l}\text { Collinearity } \\
\text { Statistics }\end{array}$} \\
\cline { 2 - 6 } & & $\begin{array}{l}\text { Zero } \\
\text { Order }\end{array}$ & Partial & Part & Tolerance & VIF \\
\hline 1 & $\mathrm{X} 1$ & $\mathbf{. 7 8 6}$ & -.086 & -.045 & .312 & 4.189 \\
& $\mathrm{X} 2$ & .895 & .790 & .563 & .312 & 4.189 \\
\hline
\end{tabular}

The result of the correlation test between the variables $\mathrm{X} 1$ and $\mathrm{Y}$ is 0.786. Based on the guidelines for the interpretation of the correlation coefficient by Anas Sudijiono, this figure is in the high or strong category, namely between $0.70-0.90$. 
The results of the regression test using the SPSS program were taken from a questionnaire related to the problem of the level of change in the leadership of the head of madrasah on the professional competence of teachers in Madrasah Ibtidaiyah Muhammadiyah, Bontonompo, and Bontonompo Selatan Districts, Gowa Regency, which consisted of 15 question items each. The data collection is intended to provide answers to the questions in the research objective, namely to describe the influence of the headmaster's leadership on the professional competence of teachers in Madrasah Ibtidaiyah Muhammadiyah, Bontonompo and South Bontonompo Districts, Gowa Regency, the following statistical data are obtained:

\begin{tabular}{|l|l|l|l|l|}
\hline \multirow{2}{*}{ Model } & \multicolumn{4}{|c|}{} \\
\cline { 2 - 5 } & $\mathbf{R}$ & $\begin{array}{l}\text { R } \\
\text { Square }\end{array}$ & $\begin{array}{l}\text { Adjusted } \\
\text { R Square }\end{array}$ & $\begin{array}{l}\text { Std. Error } \\
\text { of } \\
\text { Estimate }\end{array}$ \\
\hline 1 & .790 & .675 & .985 & 5.145567 \\
\hline
\end{tabular}

The result of the regression test between variables X1 and $y$ is 0.790 which indicates that there is a change in the strong influence between the two variables.

The results of the linearity test using the SPSS program were taken from a questionnaire related to the problem of the straight-line relationship between the head of madrasah and the professional competence of teachers in 
Madrasah Ibtidaiyah Muhammadiyah, Bontonompo, and South Bontonompo Districts, Gowa Regency, which consisted of 15 question items each. The data collection is intended to provide answers to the questions in the research objective, namely to describe the influence of the headmaster's leadership on the professional competence of teachers in Madrasah Ibtidaiyah Muhammadiyah, Bontonompo and South Bontonompo Districts, Gowa Regency.

The results of the T-test (T-Test) using the SPSS program were taken from a questionnaire related to the problem of the level of significance of the head of madrasah's leadership on the professional competence of teachers in Madrasah Ibtidaiyah Muhammadiyah, Bontonompo, and Bontonompo Selatan Districts, Gowa Regency, which consisted of 15 items each. question. The data collection is intended to provide answers to the questions in the research objective, namely to describe the influence of the headmaster's leadership on the professional competence of teachers in Madrasah Ibtidaiyah Muhammadiyah, Bontonompo and South Bontonompo Districts, Gowa Regency, the following statistical data are obtained:

\begin{tabular}{|l|l|l|l|l|l|}
\hline Model & \multicolumn{2}{|l|}{$\begin{array}{l}\text { Unstandardized } \\
\text { Coefficients }\end{array}$} & $\begin{array}{l}\text { Standardized } \\
\text { Coefficients }\end{array}$ & & \\
\cline { 2 - 6 } & B & Std Error & Beta & T & Siq. \\
\hline 1 (Constant) & 5.736 & 0.442 & & 4.076 & 0.000 \\
\hline
\end{tabular}




\begin{tabular}{|l|l|l|l|l|l|}
\hline $\mathrm{X} 1$ & 0.320 & 0.098 & 0.290 & $\mathbf{0 . 3 7 9}$ & 0.050 \\
$\mathrm{X} 2$ & 0.950 & 0.098 & 0.895 & 0.990 & 0.050 \\
\hline
\end{tabular}

The result of the T-test (T-Test) between variables X1 and $\mathrm{Y}$ shows that the $\mathrm{T}$ count is 0.379 . While the $\mathrm{T}$ table at a significance level of $5 \%(0.05)$ is 0.992 , thus there is a significant influence between variables $\mathrm{X} 1$ and $\mathrm{Y}$ were 0.379 $\leq 0.992$.

\section{The Influence of the Madrasah Environment on the Professional Competence}

The results of the correlation test using the SPSS program were taken from a questionnaire related to the relationship between the madrasah environment and the professional competence of teachers in Madrasah Ibtidaiyah Muhammadiyah, Bontonompo, and Bontonompo Selatan Districts, Gowa Regency, which consisted of 15 question items each. The data collection is intended to provide answers to the questions in the research objective, namely to describe the influence of the headmaster's leadership on the professional competence of teachers in Madrasah Ibtidaiyah Muhammadiyah, Bontonompo and South Bontonompo Districts, Gowa Regency, the following statistical data are obtained: 


\begin{tabular}{|c|c|c|c|c|c|}
\hline \multirow{2}{*}{ Model } & \multicolumn{3}{|c|}{ Correlations } & \multicolumn{2}{|c|}{$\begin{array}{l}\text { Collinearity } \\
\text { Statistics }\end{array}$} \\
\hline & $\begin{array}{l}\text { Zero } \\
\text { Order }\end{array}$ & Partial & Part & Tolerance & VIF \\
\hline $1 \mathrm{X} 1$ & .786 & -.086 & -.045 & .312 & 4.189 \\
\hline $\mathrm{X} 2$ & .895 & .790 & .563 & .312 & 4.189 \\
\hline
\end{tabular}

The result of the correlation test between the X2 and $\mathrm{Y}$ variables is 0.895. Based on the guidelines for the interpretation of the correlation coefficient by Anas Sudijiono, this figure is in the high or strong category, namely between $0.70-0.90$.

The results of the regression test using the SPSS program using SPSS program were taken from a questionnaire related to the problem of the level of change in the madrasah environment on the professional competence of teachers in Madrasah Ibtidaiyah Muhammadiyah, Bontonompo, and Bontonompo Selatan Districts, Gowa Regency, which consisted of 15 question items each. The data collection is intended to provide answers to the questions in the research objective, namely to describe the influence of the headmaster's leadership on the professional competence of teachers in Madrasah Ibtidaiyah Muhammadiyah, Bontonompo and South Bontonompo Districts, Gowa Regency, the following statistical data are obtained: 


\begin{tabular}{|l|l|l|l|l|}
\hline \multirow{2}{*}{ Model } & \multicolumn{4}{|c|}{} \\
\cline { 2 - 5 } & $\mathbf{R}$ & R Square & $\begin{array}{l}\text { Adjusted R } \\
\text { Square }\end{array}$ & $\begin{array}{l}\text { Std. Error } \\
\text { of Estimate }\end{array}$ \\
\hline 1 & .871 & .675 & .985 & 5.145567 \\
\hline
\end{tabular}

The results of the linearity test using the SPSS program using the SPSS program were taken from a questionnaire related to the problem of the straight-line relationship of the madrasah environment to the professional competence of teachers in Madrasah Ibtidaiyah Muhammadiyah, Bontonompo and Bontonompo Selatan Districts, Gowa Regency, which consisted of 15 question items each. . The data collection is intended to provide answers to the questions in the research objective, namely to describe the influence of the headmaster's leadership on the professional competence of teachers in Madrasah Ibtidaiyah Muhammadiyah, Bontonompo and South Bontonompo Districts, Gowa Regency.

Based on the results of the research that the authors collected from processed questionnaires and through data processing, it can be seen as follows:

\section{Leadership of the Head of Madrasah}

The results of the questionnaire process showed that the leadership of the head of madrasah in Madrasah Ibtidaiyah Muhammadiyah, Bontonompo, and South Bontonompo 
Districts, Gowa Regency was in the high category with an average answer score of 70 respondents of 56.70. These results are categorized as high, namely at the level of 44.33 58.98. So it can be concluded that the leadership of the head of Madrasah Ibtidaiyah Muhammadiyah in Bontonompo and South Bontonompo Districts, Gowa Regency is in the high category. The high average number of respondents' answers shows that the role of the head of Madrasah Ibtidaiyah Muhammadiyah in Bontonompo and South Bontonompo Districts, Gowa Regency is classified as something important and needed so that the existence of the head of the madrasah in leading cannot be separated from all activities that occur at every Muhammadiyah Ibtidaiyah Madrasah in the District. Bontonompo and Bontonompo Selatan, Gowa Regency.

The results of this study are under the theory put forward by Rahman which states that leadership is the ability and the art of obtaining results through activities by informing others to achieve predetermined goals. The leadership of the head of Madrasah Ibtidaiyah Muhammadiyah in Bontonompo and South Bontonompo Districts, Gowa Regency which is classified as high is expected to improve the quality of learning in achieving national education goals.

\section{The Environmental of Madrasah}

The results of the questionnaire process showed that the madrasah environment in Madrasah Ibtidaiyah Muhammadiyah, Bontonompo and South Bontonompo Districts, Gowa Regency, from the answers of 70 respondents 
was 58.64. These results are categorized as high, namely at the level of 44.29 - 58.92. So it can be concluded that the environment of Muhammadiyah Madrasah Ibtidaiyah in Bontonompo and South Bontonompo Districts, Gowa Regency is in the high category. The high average of respondents' answers shows that the environmental conditions of the Muhammadiyah Madrasah Ibtidaiyah in Bontonompo and South Bontonompo Districts, Gowa Regency are classified as something urgent and provide an important role where the existing madrasah environment plays a role in all activities and activities that occur for all elements that are around the Madrasah. Ibtidaiyah Muhammadiyah in Bontonompo and South Bontonompo Districts, Gowa Regency.

The results of this study are by the theory put forward by Soegeng Pridjodarminto which states that the school/madrasah environment is the number of all living and inanimate objects and all conditions that exist in formal educational institutions that systematically implement educational programs. The environmental conditions of Madrasah Ibtidaiyah Muhammadiyah in Bontonompo and South Bontonompo Districts, Gowa Regency, which are classified as high with a variety of structures, are expected to improve the quality of learning in achieving national education goals.

\section{The Professional Competence of Madrasah Ibtidaiyah Muhammadiyah Teachers}


The results of the questionnaire process showed that the professional competence of teachers in Madrasah Ibtidaiyah Muhammadiyah, Bontonompo and South Bontonompo Districts, Gowa Regency, from the answers of 70 respondents was 57.28 . These results are categorized as high, namely at the level of 44.23 - 58.83. So it can be concluded that the professional competence of Madrasah Ibtidaiyah Muhammadiyah teachers in Bontonompo and South Bontonompo Districts, Gowa Regency is categorized as high. The high average number of respondents' answers shows the professional competence of Madrasah Ibtidaiyah Muhammadiyah teachers in Bontonompo and South Bontonompo Districts, Gowa Regency, which are considered important and needed in the world of education so that competent and professional teachers play a role in all activities and activities that occur in the education process of Madrasah Ibtidaiyah. Muhammadiyah in Bontonompo and South Bontonompo Districts, Gowa Regency.

The results of this study are by the theory put forward by Irawan and Siahaan which states that the professional competence of teachers includes mastery of academic study materials, conducting research and compiling scientific papers, professional development, and understanding educational insights. The high professional competence of Madrasah Ibtidaiyah Muhammadiyah teachers in Bontonompo and South Bontonompo Districts, Gowa Regency, is expected to improve the quality of learning in achieving national education goals. 


\section{The Influence of Principal Leadership}

The processed questionnaire shows that the influence of the headmaster's leadership on the professional competence of Madrasah Ibtidaiyah Muhammadiyah teachers in Bontonompo and Bontonompo Selatan Districts, Gowa Regency is classified as positive. The result of the T-test ( $\mathrm{T}$ Test) between variables $\mathrm{X} 1$ and $\mathrm{Y}$ shows that the $\mathrm{T}$ count is 0.379 . While the $\mathrm{T}$ table at a significance level of $5 \%(0.05)$ of 0.992 , thus there is a significant influence between variables $\mathrm{X} 1$ and $\mathrm{Y}$ were $0.379 \leq 0.992$. The result of the correlation test between the variables $\mathrm{X} 1$ and $\mathrm{Y}$ is 0.786 . Based on the guidelines for the interpretation of the correlation coefficient by Anas Sudijiono, this figure is in the high or strong category, namely between $0.70-0.90$. The results of the regression test between variables $\mathrm{X} 1$ and $\mathrm{y}$ were 0.790 which indicated that there was a strong change in influence between the two variables, while the results of the linearity test based on the observed cum prob diagram images X1 and X2 and Y showed that it was close to a straight line which was 0.996 at the $5 \%$ significance level $(0,05)$.

The results of this study relate to Kreitner's theory in E. Mulyasa which states that leadership is a process of influencing others in which a leader invites subordinates to voluntarily participate in achieving organizational goals. Leadership is important in achieving goals, especially in this case related to the problem of leadership in Madrasah Ibtidaiyah Muhammadiyah in Bontonompo and 
Bontonompo Districts, Gowa Regency which is classified as positive. We can know these results from the achievements of students and madrasas in Bontonompo and South Bontonompo Districts, Gowa Regency. These achievements are both in the form of student learning outcomes and awards obtained by the respective madrasahs in Bontonompo and Bontonompo Selatan Districts, Gowa Regency.

\section{The Influence of the Madrasah Environment on the Professional Competence}

The processed questionnaire shows that the influence of the madrasah environment on the professional competence of Madrasah Ibtidaiyah Muhammadiyah teachers in Bontonompo and Bontonompo Selatan Districts, Gowa Regency is classified as positive. The result of the T-test ( $\mathrm{T}$ Test) between the variables $\mathrm{X} 2$ and $\mathrm{Y}$ shows that $\mathrm{T}$ count is 0.990. While the $\mathrm{T}$ table at a significance level of $5 \%(0.05)$ is 0.992, thus there is a significant influence between the variables $\mathrm{X} 2$ and $\mathrm{Y}$ were $0.990 \leq 0.992$. The result of the correlation test between the $\mathrm{X} 2$ and $\mathrm{Y}$ variables is 0.895 . Based on the guidelines for the interpretation of the correlation coefficient by Anas Sudijiono, this figure is in the high or strong category, namely between $0.70-0.90$. The results of the regression test between variables X2 and Y were 0.871 which indicated that there was a strong change in influence between the two variables, namely between the variables $\mathrm{X} 2$ and $\mathrm{Y}$, while the results of the linearity test based on the observed cum prob X2 and Y diagrams showed that it 
was close to a straight line which was equal to 0.995 at the significance level. 5\% (0.05).

The results of this study are related to Muhammad Surya's theory which states that the school environment includes living objects in the form of the closest human being in the form of the closest human that surrounds him, namely the family. Family is the main and first educational environment because humans get education for the first time from the family environment before knowing other environments. Apart from that, humans get family education starting in the womb and during the toddler period (preschool). the influence of the madrasah environment on the professional competence of Madrasah Ibtidaiyah Muhammadiyah teachers in Bontonompo and South Bontonompo Districts, Gowa Regency which is classified as positive. We can know these results from the physical and mental conditions as well as the achievements of the teachers and students who are in good health. A healthy and conducive environment can have a positive influence on the creatures in it.

\section{The Influence of Madrasah Principal Leadership and Madrasah Environment on Professional Competence}

The results of the questionnaire processed show that the influence of the leadership of the head of madrasah and the madrasah environment together on the professional competence of Madrasah Ibtidaiyah Muhammadiyah teachers in Bontonompo and South Bontonompo Districts, Gowa 
Regency is not positive. The results of the F test (F - Test) between the variables $\mathrm{X} 1$ and $\mathrm{X} 2$ against $\mathrm{Y}$ show that $\mathrm{F}$ counts for 0.998. While the $\mathrm{F}$ table at the $5 \%(0.05)$ significance level is 0.873 , thus there is no significant effect between variables $\mathrm{X} 1$ and $\mathrm{X} 2$ on $\mathrm{Y}$ were $0.998 \geq 0.873$. The result of the multiple correlation test between variables $\mathrm{X} 1$ and $\mathrm{X} 2$ on $\mathrm{Y}$ is 0.818 . Based on the guidelines for the interpretation of the correlation coefficient by Anas Sudijiono, this figure is in the high or strong category, namely between $0.70-0.90$. The results of the multiple regression test between variables $\mathrm{X} 1$ and $\mathrm{X} 2$ on $\mathrm{Y}$ are 0.675 which indicates that there is a change in the influence that is quite strong between the two variables while the results of the linearity test based on the observed cum prob diagram Figure X1 and X2 and $\mathrm{Y}$ show that it is close to a straight line which is equal to 0.996 at the significance level. $5 \%(0.05)$.

\section{Conclusion}

This research has several conclusions, including:

The leadership of the Head of Madrasah Ibtidaiyah Muhammadiyah in Bontonompo and South Bontonompo Districts, Gowa Regency is categorized as high or strong. Also, the environment of Muhammadiyah Madrasah Ibtidaiyah in Bontonompo and South Bontonompo Districts, Gowa Regency is categorized as high or strong. The professional competence of Madrasah Ibtidaiyah Muhammadiyah teachers in Bontonompo and South Bontonompo Districts, Gowa regency is categorized as high 
or strong. The influence of the Leadership of Madrasah Principals on the Professional Competence of Muhammadiyah Ibtidaiyah Teachers in Bontonompo and Bontonompo Districts, Gowa Regency is positive. The influence of the Madrasah Environment on the Professional Competence of Muhammadiyah Ibtidaiyah Teachers in Bontonompo and South Bontonompo Districts, Gowa Regency. The influence of the Leadership of the Madrasah Principal and the Madrasah Environment collectively on the Professional Competence of Madrasah Ibtidaiyah Muhammadiyah Teachers in Bontonompo and Bontonompo Selatan Districts, Gowa Regency is not positive.

\section{REFERENCES}

Bachri, Syamsul Thalib. (2013) Educational Psychology Based on Applicative Empirical Analysis. Cet. II; Jakarta: Kencana Prenamedia Group,

Brannen, Julia, (2002) Combining Qualitative and Quantitative Research Methods. Cet. III; Yogyakarta: Student Library, Fourth Edition,

Ministry of Religion of the Republic of Indonesia, (2013). AlQur'an and its translations. Jakarta: Kencana,

Hamalik, Oemar. (2008) Teacher Education Based on a Competency Approach. Cet. V; Jakarta: Bumi Aksara, 2008. Mulyasa, Becoming a Professional Teacher, Creating Creative and Fun Learning. Cet. VII; Bandung: Youth Rosda Karya, 
Idris, Muhamad. (2008) Tips to Become a Professional Teacher. Cet. I; Yogyakarta: Ar-Ruzz Media,

Saroni, Muhamad, (2006) Madrasah Management. Cet. II; Yogyakarta: Ar Russ.

Supardi, Imam., (2003) Environment and Sustainability. Cet. II; Bandung: PT Alumni.

Uno, B. Hamzah., (2009) Educational Professions, Problems, Solutions, and Educational Reform in Indonesia. Cet. IV; Jakarta: Earth Literacy, 